\title{
Identification of potential soil adsorbent for the removal of hazardous metals from aqueous phase
}

\author{
J. N. Bhakta $\cdot$ Y. Munekage
}

Received: 20 November 2011 / Revised: 31 May 2012/Accepted: 2 August 2012/Published online: 14 December 2012

(c) CEERS, IAU 2012

\begin{abstract}
The present study attempted to identify the efficient hazardous metal-removing sorbent from specific types of soil, upper and middle layer shirasu, shell fossil, tuff, akadama and kanuma soils of Japan by physicochemical and metal (arsenic, cadmium and lead) removal characterizations. The physico-chemical characteristics of soil were evaluated using X-ray diffraction and scanning electron microscopy with energy dispersive spectroscopy techniques, whereas metal removal properties of soil were characterized by analyzing removal capacity and sorption kinetics of potential metal-removing soils. The chemical characteristics revealed that all soils are prevalently constituted of silicon dioxide (21.83-78.58\%), aluminum oxide (4.13-38\%) and ferrous oxide (0.835-7.7\%), whereas calcium oxide showed the highest percentage $(65.36 \%)$ followed by silicon dioxide $(21.83 \%)$ in tuff soil. The results demonstrated that arsenic removal efficiency was higher in elevated aluminum oxide-containing akadama $(0.00452 \mathrm{mg} / \mathrm{L} / \mathrm{g} / \mathrm{h})$ and kanuma $(0.00225 \mathrm{mg} / \mathrm{L} /$ $\mathrm{g} / \mathrm{h})$ soils, whereas cadmium $(0.00634 \mathrm{mg} / \mathrm{L} / \mathrm{g} / \mathrm{h})$ and lead $(0.00693 \mathrm{mg} / \mathrm{L} / \mathrm{g} / \mathrm{h})$ removal efficiencies were maximum in elevated calcium oxide-containing tuff soil. Physico-
\end{abstract}

\footnotetext{
J. N. Bhakta $(\square)$

Research Institute of Molecular Genetics, Kochi University, B200, Monobe, Nankoku, Kochi 783-8502, Japan

e-mail: 1snjbhakta@gmail.com
}

J. N. Bhakta · Y. Munekage

Department of Environmental Engineering,

Faculty of Agriculture, Kochi University,

B200, Monobe, Nankoku, Kochi 783-8502, Japan

Present Address:

J. N. Bhakta

International Centre of Ecological Engineering,

University of Kalyani, Kalyani 741-235, India chemical sorption and ion exchange processes are the metal removal mechanisms. The critical appraisal of three metal removal data also clearly revealed cadmium $>$ lead $>$ arsenic order of removal efficiency in different soils, except in tuff and akadama soils followed by lead $>$ cadmium $>$ arsenic. It clearly signified that each type of soil had a specific metal adsorption affinity which was regulated by the specific chemical composition. It may be concluded that akadama would be potential arsenicremoving and tuff would be efficient cadmium and leadremoving soil sorbents.

Keywords Isotherm - Removal efficiency .

Scanning electron microscopy $\cdot$ Soil characterization .

$\mathrm{X}$-ray diffraction

\section{Introduction}

Contamination of hazardous metals into aquatic environment is a growing concern worldwide because it has caused severe and persistent hazardous problems in different domains of the environment during the last few decades. Of the 11 hazardous priority substances in the list of pollutants contained in the Water Framework Directive, arsenic (As), cadmium $(\mathrm{Cd})$ and lead $(\mathrm{Pb})$ are the major ones (Directive 2000/60/EC 2000). Discharge of hazardous metal-contaminated effluents into the environment is a tremendous problem affecting water and soil quality, and hence presenting a direct danger to human health and various forms of life (Aksu 2005; Kratochvil and Volesky 1998). Arsenic, $\mathrm{Cd}$ and $\mathrm{Pb}$ can cause various dysfunctions and chronic alterations in the nervous system and gastrointestinal tract even at low concentrations (Choudhury and Mudipalli 2008; Roberts 1999). Allergies 
are not uncommon and repeated long-term contact with some metals or their compounds may even cause cancer (International Occupational Safety and Health Information Centre 1999).

The surface and groundwater contamination by As has already been reported as a cause of acute toxic metal poisoning with severe health risks by various scientists (Hemond and Solo-Gabriele 2004; Murphy et al. 1989). Despite the presence of various chemical and glass industries, the weathering process of rocks is the primary cause of As contamination in water and soils. According to Robertson (1989), the main natural sources of this element in soils are As-bearing rocks and minerals. Cadmium is a biologically nonessential, non-biodegradable, persistent type of 'priority pollutant' (Campbell 2006) that easily accumulates in sediments and aquatic organisms (by bioaccumulation and biomagnifications), thus causing a gross biological impact. The sources of $\mathrm{Cd}$ contamination are mining and smelting processes of lead and zinc, nickel-cadmium batteries, polyvinyl chloride plastics, paint pigments, insecticides, fungicides and commercial fertilizer industries. Lead has been used by man for many years and can be regarded as a long-lasting environmental pollutant. Industry produces about 2.5 million tons of $\mathrm{Pb}$ per year throughout the world and is used in producing storage batteries, insecticides, plastic water pipes, beverages, ointments and medical concoctions for flavoring and sweetening (Nadeem et al. 2005) that ultimately lead to aquatic contamination.

Thus, industrial and agricultural wastewater effluents contain one or more of these toxic metals with rather higher concentrations than permissible discharge levels of effluents. Therefore, it becomes necessary to remove metals from wastewater to a feasible extent by an appropriate treatment to control the problem of hazardous metal pollution in the environment. Various improved and innovative methods such as reverse osmosis, precipitation, coagulation, ion exchange, solvent extraction, adsorption, membrane filtration, ultra-filtration and photoreduction have been developed to remove metal pollutants from contaminated water and wastewater (Bailey et al. 1999; Barron-Zambrano et al. 2002; Chen and Wang 2000; Hunsom et al. 2005; Kentish and Stevens 2001; Pacheco et al. 2006). Among the above-mentioned processes, adsorption plays a pivotal role in removing metals from the aqueous phase using various biomaterial sorbents, algae (Holan et al. 1993), fungi, sugar cane bagasse (Cerino Córdova et al. 2011; Peterlene et al. 1999), rice husk, wheat barn (Nouri et al. 2007), pine bark, olive cake (Doyurum and Celik 2006), coconut husk, chitin (Benguella and Benaissa 2002), ash, activated carbon (Jusoh et al. 2007; Onundi et al. 2011; Zavvar Mousavi and Seyedi 2011), etc. Clays, zeolite, calcite, manganese nodule residue (Agrawal and Sahu 2006; Tashauoei et al. 2010), perlite (Hasan et al.
2006) and peat (Gabaldon et al. 2006) have also been employed to remove metals from the water phase. Also, low-cost natural clay/soil is used to develop highthroughput inorganic adsorbent as well as membrane filter in removing heavy metals from aqueous phase. Clay/soil and waste materials are used as modified potential tools in removing heavy metals and various toxic compounds for the reclamation of the aquatic environment (Bhakta and Munekage 2008, 2009).

On account of the above, it is also apparent that some of the metal removal techniques are inadequate and expensive in the practical field. Moreover, materials used in these techniques are not sufficiently available and very expensive to treat the massive amount of effluent water; it is unaffordable for small-scale industries especially in underdeveloped as well as developing countries. Therefore, an affordable, low-cost metal removal technology is required. The aquatic ecosystem minimizes and balances the negative impact of hazardous compounds by a mechanism using abiotic and biotic ecosystem components, for example, sediment and aquatic organisms remove heavy metals from water and accumulate within them (Bhakta and Munekage 2008; Das and Jana 1999; Ferard et al. 1983; Jana and Das 1997). Stemming from the above understanding, the development of promising, eco-friendly and low-cost water reclamation technology using potential sorption criteria of specific soil is important and necessary in the present hazardous metal polluting scenario of aquatic environment. From the above points of view, therefore, the present study has been aimed at finding out the As-, $\mathrm{Cd}$ - and $\mathrm{Pb}$-specific efficient soil adsorbents by assessing (1) physico-chemical and (2) metal sorption properties of soils to remove hazardous metals from the aqueous phase. The study was carried out in 2009 at the Department of Environmental Engineering, Kochi University, Kochi, Japan.

\section{Materials and methods}

Soil, sampling and processing

The present study selected six kinds of specific soil, procured from different parts of Japan, including upper layer shirasu $\left(\mathrm{S}_{1}, \mathrm{pH} 6.57\right)$, middle layer shirasu $\left(\mathrm{S}_{2}, \mathrm{pH} 7.01\right)$ and lower layer shell fossil $\left(\mathrm{S}_{3}, \mathrm{pH}\right.$ 9.22) soils of Kagoshima prefecture $\left(31^{\circ} 37^{\prime} \mathrm{N}, 130^{\circ} 32^{\prime} \mathrm{E}\right)$, tuff soil $\left(\mathrm{S}_{4}, \mathrm{pH}\right.$ $9.03)$ of Shimane prefecture $\left(35^{\circ} 10^{\prime} 59^{\prime \prime} N, 132^{\circ} 30^{\prime} E\right)$, akadama $\left(\mathrm{S}_{5}, \mathrm{pH}\right.$ 6.09) and kanuma soils $\left(\mathrm{S}_{6}, \mathrm{pH}\right.$ 5.25) of Tochigi prefecture $\left(36^{\circ} 45^{\prime} N, 139^{\circ} 45^{\prime} E\right)$. The diversified physico-chemical specificities of soils compared to other soils found in Japan are the primary basis for the selection of soils (Table 1). Moreover, soil types $S_{1}-S_{3}$ are frequently used in ceramic production, whereas $S_{5}$ and $S_{6}$ 
Table 1 Physico-chemical characteristics of soils employed in the study

\begin{tabular}{|c|c|c|}
\hline Soil types and location & Local name of Soil & Collected layer and physical nature of soil \\
\hline $\begin{array}{l}\text { Meadow soil association, } \\
\text { Kagoshima }\end{array}$ & $\begin{array}{l}\text { Upper layer shirasu } \\
\text { soil }\left(\mathrm{S}_{1}\right)\end{array}$ & $\begin{array}{l}\text { Top layer of shirasu soil }(0.5 \mathrm{~m}) \text {. Coarse whitish, sandy in nature. } \\
\text { No detectable amount of organic matter content was found }\end{array}$ \\
\hline $\begin{array}{l}\text { Meadow soil association, } \\
\text { Kagoshima }\end{array}$ & $\begin{array}{l}\text { Middle layer shirasu } \\
\text { soil }\left(\mathrm{S}_{2}\right)\end{array}$ & $\begin{array}{l}\text { Collected from } 2 \mathrm{~m} \text { depth of shirasu soil. Fine whitish, sandy in nature. } \\
\text { No detectable amount of organic matter content was found }\end{array}$ \\
\hline $\begin{array}{l}\text { Meadow soil association, } \\
\text { Kagoshima }\end{array}$ & $\begin{array}{l}\text { Lower layer shell fossil } \\
\text { soil }\left(\mathrm{S}_{3}\right)\end{array}$ & $\begin{array}{l}\text { Four meter depth of shirasu soil is fine, whitish in color. No detectable } \\
\text { amount of organic matter content was found }\end{array}$ \\
\hline $\begin{array}{l}\text { Meadow soil association, } \\
\text { Shimane }\end{array}$ & Tuff soil $\left(\mathrm{S}_{4}\right)$ & $\begin{array}{l}\text { Collected from surface layer of volcanic soil in this region. It has } \\
\text { cement-like physical appearance and heavier than land soil due to having } \\
\text { ash fragments of rock. No detectable amount of organic matter content was found }\end{array}$ \\
\hline $\begin{array}{l}\text { Recent volcanic soil, } \\
\text { Tochigi }\end{array}$ & Akadama soil $\left(\mathrm{S}_{5}\right)$ & $\begin{array}{l}\text { Located at } 2 \mathrm{~m} \text { depth of volcanic ash soil, brown in color. It is fluffy, } \\
\text { loamy soil and a bit heavier than kanuma. Organic matter content was } 0.09 \%\end{array}$ \\
\hline $\begin{array}{l}\text { Recent volcanic soil, } \\
\text { Tochigi }\end{array}$ & Kanuma soil $\left(\mathrm{S}_{6}\right)$ & $\begin{array}{l}\text { Three meter deeper layer of volcanic ash soil layer. It is also fluffy, less dense, very } \\
\text { lightweight and whitish yellow in color. Organic matter content was } 0.86 \%\end{array}$ \\
\hline
\end{tabular}

soils are highly porous in nature and widely used as horticulture bed for heavy water retention capacity.

Soils were collected from three places of each region, air dried, homogenized by mortar and pestle and sieved through mesh $(0.404 \mathrm{~mm})$ for the experiment.

\section{Characterization of soil}

Mineralogical characterization of soil was performed by X-ray diffraction (XRD, X'Pert PRO, Philips) in the Center for Advanced Marine Core Research, Kochi University, Japan. Morphological and chemical characterizations of soil samples were also executed by scanning electron microscopy (SEM) using a JEOL model equipment coupled with energy-dispersive spectroscopy (EDS) facility (JSM-6500F, JEOL) in the same research center.

\section{Identification of potential metal-removing soil}

The potential metal-removing soils were identified through the assessment of metal removal criteria of soils.

Metal removal experiment was carried out using 63 conical flasks $(0.1 \mathrm{~L})$ following the batch operation mode in laboratory condition $\left(20^{\circ} \mathrm{C}\right)$. All conical flasks were randomly divided into three groups $(21 \times 3)$ for three metals: $\mathrm{As}, \mathrm{Cd}$ and $\mathrm{Pb}$. Each group was further subdivided into seven batches having three replicates $(7 \times 3)$-one batch employed for control received no soil and the other six batches were used for the six types of soil (called as $\mathrm{S}_{1}-\mathrm{S}_{6}$ ). Each conical flask was provided with the respective soil at the rate of $1 \mathrm{~g} / \mathrm{L}$ and filled with As solution $(0.5 \mathrm{mg} / \mathrm{L}, \mathrm{pH} 7.62)$ in the first group, Cd solution $(0.5 \mathrm{mg} / \mathrm{L}$, $\mathrm{pH} 4.35)$ in the second group and $\mathrm{Pb}$ solution $(0.5 \mathrm{mg} / \mathrm{L}$, $\mathrm{pH} 6.81$ ) in the third group at the rate of $0.1 \mathrm{~L} /$ flask. The experiment continued for $72 \mathrm{~h}$. Arsenic and $\mathrm{Cd}$ solutions were prepared from standard stock solutions of arsenic(III) trioxide $\left(\mathrm{As}_{2} \mathrm{O}_{3}\right)$ and cadmium chloride $\left(\mathrm{CdCl}_{2}\right)$ (Cica-Reagent, Kanto Chemical Co., Inc., Tokyo, Japan), respectively, whereas $\mathrm{Pb}$ solution was prepared using lead(II) nitrate $\left(\mathrm{Pb}\left(\mathrm{NO}_{3}\right)_{2}\right.$, Sigma-Aldrich Chemical GmbH, Germany).

Metal removal criteria of six different soils were determined by calculating the metal removal efficiency (MRE) using the modified equation of Bhakta and Munekage (2008) as follows:

$\operatorname{MRE}=\frac{C_{\mathrm{i}}-C_{\mathrm{f}}}{M\left(t_{\mathrm{f}}-t_{\mathrm{i}}\right)}$

where $C_{\mathrm{i}}$ and $C_{\mathrm{f}}$ are the initial and final concentrations $(\mathrm{mg} / \mathrm{L})$, respectively; $M$ is the mass $(\mathrm{g})$ of soil and $t_{\mathrm{i}}$ and $t_{\mathrm{f}}$ are the initial and final times (h).

Sorption isotherm of the identified potential metal-removing soil

After selection of potential metal-removing soils, the isotherm studies of soil-specific metals (As or $\mathrm{Cd}$ or $\mathrm{Pb}$ ) were performed by batch operation mode using the effect of soil doses in removing metals from water. Different doses of As-removing soil (2, 4, 6, 8 and $10 \mathrm{~g} / \mathrm{L})$, Cd-removing soil $(1,2,3,4$ and $5 \mathrm{~g} / \mathrm{L})$ and $\mathrm{Pb}$-removing soil $(0.5,1,2,5$ and $10 \mathrm{~g} / \mathrm{L})$ were used in glass bottles $(0.2 \mathrm{~L})$ to equilibrate the known concentration $(10 \mathrm{mg} / \mathrm{L})$ of the respective metalsAs, $\mathrm{Cd}$ and $\mathrm{Pb}$ solutions $(0.1 \mathrm{~L})$ prepared from the abovementioned standards. All glass bottles were shaken in a reciprocating shaker with a capacity of 200 excursions/min (epm) at $25{ }^{\circ} \mathrm{C}$ for a contact period of $12 \mathrm{~h}$.

At equilibrium, the amounts of target metals adsorbed $\left(q_{\mathrm{e}}, \mathrm{mg} / \mathrm{g}\right.$ ) onto the corresponding soils were found by following mass balance relationship equation (Eq. 2) (Rozada et al. 2008): 
$q_{\mathrm{e}}=\frac{\left(C_{0}-C_{\mathrm{e}}\right) V}{M}$

where $C_{0}(\mathrm{mg} / \mathrm{L})$ and $C_{\mathrm{e}}(\mathrm{mg} / \mathrm{L})$ are the initial and the equilibrium water phase concentrations of metal, respectively, $V(\mathrm{~L})$ is the volume of the solution and $M(\mathrm{~g})$ is the mass of soil.

The results were fitted following the equations of Langmuir (Eq. 3) and Freundlich (Eq. 4) isotherm models described by Rozada et al. (2008) as below:

$q_{\mathrm{e}}=\frac{Q^{0} K_{\mathrm{L}} C_{\mathrm{e}}}{1+K_{\mathrm{L}} C_{\mathrm{e}}}$

where $Q^{0}(\mathrm{mg} / \mathrm{g})$ and $K_{\mathrm{L}}(\mathrm{L} / \mathrm{mg})$ are the Langmuir parameters related to the maximum capacity of adsorption and to the binding energy of adsorption, respectively.

$q_{\mathrm{e}}=K_{\mathrm{F}} C_{\mathrm{e}}^{1 / n}$

where $K_{\mathrm{F}}(\mathrm{L} / \mathrm{mg})$ is the Freundlich constant, $C_{\mathrm{e}}(\mathrm{mg} / \mathrm{g})$ is the equilibrium liquid phase concentration and $1 / n$ is the heterogeneity factor.

Practical approach of metal-contaminated water treatment: sorption, desorption and resorption

Ten liters of each metal $(1 \mathrm{mg} / \mathrm{L})$-challenged water was made with the above-mentioned standard solutions and employed for sorption study using potential metal-removing soils. Each metal (As or $\mathrm{Cd}$ or $\mathrm{Pb}$ )-challenged water (10 L) was treated with $10 \mathrm{~g}(1 \mathrm{~g} / \mathrm{L})$ of the respective identified soil in the treatment chamber of the experimental apparatus and continuously mechanically agitated (200 epm) for $6 \mathrm{~h}$. The initial and final $\mathrm{pH}$ of the treated water were measured. To quantify the desorption capacity, metals (As, $\mathrm{Cd}$ and $\mathrm{Pb}$ ) loaded above soils were collected, gently washed (once) by Milli Q water to remove unbound metals and centrifuged. One gram of each washed soil was agitated with $10 \mathrm{mmol} / \mathrm{L}$ EDTA (ethylenediamine teraacetic acid as desorbent) solution at the rate of $1 \mathrm{~g} / \mathrm{L}$ for $60 \mathrm{~min}$ and the concentration of the metal in the solution was examined. Reusability was assessed by the resorption process using the above desorbed soils. One gram of each dried desorbed soil was employed in $1 \mathrm{~L}$ of the respective metal solutions $(1 \mathrm{mg} / \mathrm{L})$ to determine the percentage resorption capacity.

Analysis of metals

Water samples were collected from experimental vesicles, centrifuged and analyzed using the atomic absorption spectrophotometer (Analyst 200, Perkin Elmer) to determine $\mathrm{As}, \mathrm{Cd}$ and $\mathrm{Pb}$ metal contents of water at the wavelengths 193.7, 228.8 and $422.67 \mathrm{~nm}$, respectively.
Concentrations of $\mathrm{Na}, \mathrm{K}, \mathrm{Ca}$ and $\mathrm{Mg}$ in water were examined by ion chromatography (ICS 900, Dionex Corporation, Sunnyvale, CA, USA) using a CS12A column. Ten milliliters of filtered water was used for ion chromatography following the conditions: flow rate $1 \mathrm{~mL} / \mathrm{min}$, pressure $1,100-1,200 \mathrm{psi}$ and temperature $20^{\circ} \mathrm{C}$.

Statistical analysis

Data (mean of three replicates) obtained from the experiments were used for statistical analysis using one-way ANOVA (Gomez and Gomez 1984). In case of significant difference, the ANOVA was followed by an LSD (least significance difference) test using statistical package EASE and MSTAT. All statistical tests were performed at $5 \%$ probability level.

\section{Results and discussion}

Characterization and identification of soil

XRD patterns of the six soils are shown in Fig. 1. It shows that quartz was predominant with the presence of albite in $S_{1}$ and $S_{3}$, calcium mordenite in $S_{5}$ and anorthite in $S_{6}$, whereas $S_{2}$ was predominantly anorthite with the association of albite and $\mathrm{S}_{4}$ was predominantly magnesium calcite with quartz (Table 2).

The morphological structure and chemical composition of soils obtained from SEM-EDS analysis are shown in Fig. 2 and Table 3, respectively. The SEM of soil particles revealed a clear picture of morphological information and microscopic surface texture of soils. Table 3 shows the percentage composition of different chemical constituents obtained by EDS analysis of six soils. It was also observed that the particles of all soils predominantly constituted of silicon dioxide $\left(\mathrm{SiO}_{2}\right.$, 21.9-78.6\%), aluminum oxide $\left(\mathrm{Al}_{2} \mathrm{O}_{3}, 4.0-38 \%\right)$ and ferrous oxide ( $\mathrm{FeO}, 0.84-7.75 \%$ ) except soil $\mathrm{S}_{4}$ where calcium oxide $(\mathrm{CaO})$ showed the highest percentage $(65.4 \%)$ followed by $\mathrm{SiO}_{2}(21.9 \%)$. The percent abundance of $\mathrm{SiO}_{2}$ was highest in $\mathrm{S}_{1}$ and minimum in $\mathrm{S}_{4}$, whereas maximum and minimum abundances of $\mathrm{Al}_{2} \mathrm{O}_{3}$ were found in $\mathrm{S}_{6}$ and $\mathrm{S}_{4}$, respectively. The major chemical composition of soils is similar to that of zeolites with some exceptions. A small percentage of cuprous oxide $(\mathrm{CuO})$ was also found in $\mathrm{S}_{5}$ $(2.6 \%)$ and $\mathrm{S}_{6}(3.7 \%)$ type of soils. The remaining constituents were present in very negligible percentages.

The concentration of $\mathrm{As}, \mathrm{Cd}$ and $\mathrm{Pb}$ ranged from 0.174 to $0.5 \mathrm{mg} / \mathrm{L}, 0.043$ to $0.5 \mu \mathrm{g} / \mathrm{L}$ and 0.00048 to $0.5 \mathrm{mg} / \mathrm{L}$ in water of six types of soil throughout the period of experimentation, respectively. Significant soil-dependant responses were pronounced in $\mathrm{As}, \mathrm{Cd}$ and $\mathrm{Pb}$ adsorption process (ANOVA, $P<0.05$ ). Arsenic removal was maximum $(0.326 \mathrm{mg} / \mathrm{L})$ in $\mathrm{S}_{5}$ soil exhibiting the following order 

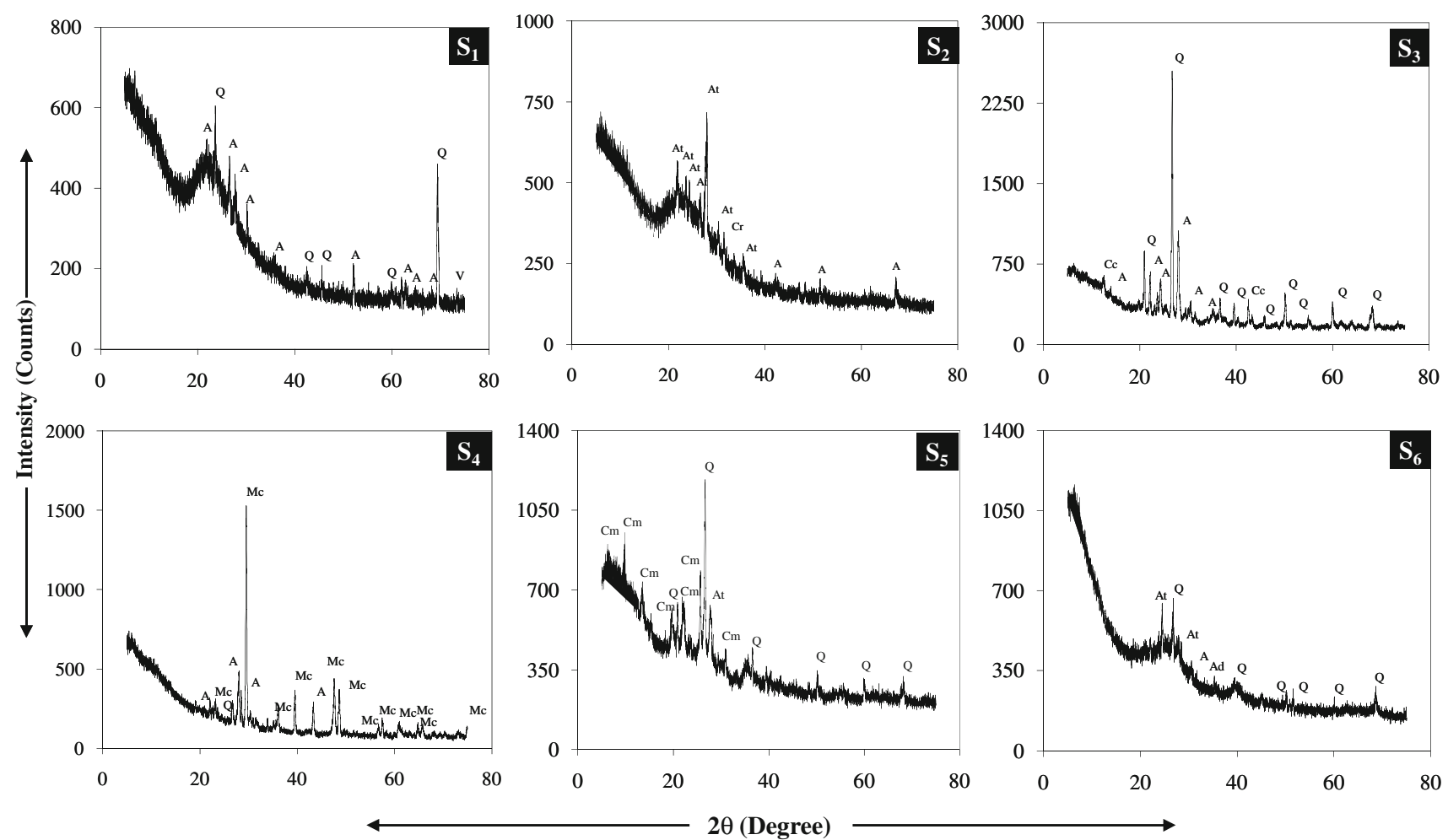

Fig. 1 XRD pattern of mineralogical characteristics of six soils $\left(\mathrm{S}_{1}-\mathrm{S}_{6}\right)$ used in the experiment $(Q$ quartz, $A$ albite, $V$ vermiculite, $A t$ anorthite, $\mathrm{Cr}$ cristobalite, $\mathrm{Cc}$ clinoclore, $\mathrm{Mc}$ magnesium calcite, $\mathrm{Ad}$ andesine and $\mathrm{Cm}$ calcium mordenite)

Table 2 XRD scores of different mineral constituents of six soils $\left(\mathrm{S}_{1}-\mathrm{S}_{6}\right)$

\begin{tabular}{lrrrrrr}
\hline Minerals & \multicolumn{7}{l}{ Types of soil } & & & \\
\cline { 2 - 7 } & $\mathrm{S}_{1}$ & $\mathrm{~S}_{2}$ & $\mathrm{~S}_{3}$ & $\mathrm{~S}_{4}$ & $\mathrm{~S}_{5}$ & $\mathrm{~S}_{6}$ \\
\hline Quartz & 33 & - & 69 & 32 & 69 & 33 \\
Albite & 22 & 33 & 53 & 28 & - & - \\
Vermiculite & 11 & - & - & - & - & - \\
Anorthite & - & 51 & - & - & 36 & 43 \\
Cristobalite & - & 28 & - & - & - & - \\
Clinoclore & - & - & 35 & - & - & - \\
Magnesium calcite & - & - & - & 70 & - & - \\
Andesine & - & - & - & - & - & 27 \\
Calcium mordenite & - & - & - & - & 44 & - \\
\hline
\end{tabular}

of variation: $S_{5}>S_{6}>S_{3}>S_{4}$ and $S_{2}>S_{1}$. Removal of As by $S_{5}$ soil was markedly higher (101-3,160\%) than that of the remaining types of soil. Arsenic concentration of water registered a gradual declining trend with time in all soils (Fig. 3). Maximum removal of $\mathrm{Cd}(0.457 \mathrm{mg} / \mathrm{L})$ was found in $\mathrm{S}_{4}$ exhibiting the following order of variation: $\mathrm{S}_{4}>\mathrm{S}_{5}>\mathrm{S}_{3}$ and $\mathrm{S}_{6}>\mathrm{S}_{2}>\mathrm{S}_{1}$ (Fig. 3). Cadmium removal of $S_{4}$ was $6.7,13.7,16.4,28.7$ and $44.6 \%$ greater than that of $\mathrm{S}_{5}, \mathrm{~S}_{3}, \mathrm{~S}_{6}, \mathrm{~S}_{2}$ and $\mathrm{S}_{1}$, respectively. Temporally, there was a sharp decreasing trend in the concentration of $\mathrm{Cd}$ at $3 \mathrm{~h}$ and gradually decreased thereafter in all soils (Fig. 3). A surprisingly elevated amount of adsorptions of $\mathrm{Pb}$ was observed in $\mathrm{S}_{4}(0.499 \mathrm{mg} / \mathrm{L})$ and $\mathrm{S}_{5}(0.489 \mathrm{mg} / \mathrm{L})$, whereas $\mathrm{S}_{1}(38 \mu \mathrm{g} /$ $\mathrm{L}$ ) showed minimum level of adsorption (Fig. 3). The total Pb adsorption of $\mathrm{S}_{4}$ was 2, 115, 371, 692 and 1,114 \% higher than that of $S_{5}, S_{3}, S_{6}, S_{2}$ and $S_{1}$, respectively. Likewise $C d$, a sharp decrement was found at $3 \mathrm{~h}$ in the $\mathrm{Pb}$ concentration of $\mathrm{S}_{4}$ and $\mathrm{S}_{5}$, and showed a slow decreasing trend in the rest of the soil types employed.

The MREs varied from 0.00014 to $0.00452 \mathrm{mg} / \mathrm{L} / \mathrm{g} / \mathrm{h}$, 0.00439 to $0.00634 \mathrm{mg} / \mathrm{L} / \mathrm{g} / \mathrm{h}$ and 0.00053 to $0.00693 \mathrm{mg} / \mathrm{L} / \mathrm{g} / \mathrm{h}$ in As, $\mathrm{Cd}$ and $\mathrm{Pb}$, respectively. Soil types $\mathrm{S}_{5}(0.00452 \mathrm{mg} / \mathrm{L} / \mathrm{g} / \mathrm{h})$ and $\mathrm{S}_{6}(0.00225 \mathrm{mg} / \mathrm{L} / \mathrm{g} / \mathrm{h})$ exhibited remarkably higher MREs in As, whereas significantly elevated MRE values of $\mathrm{Cd}$ $(0.00634 \mathrm{mg} / \mathrm{L} / \mathrm{g} / \mathrm{h})$ and $\mathrm{Pb}(0.00693 \mathrm{mg} / \mathrm{L} / \mathrm{g} / \mathrm{h})$ were observed in $\mathrm{S}_{4}$ (Fig. 4).

The results clearly demonstrated that total metal removal (As, $0.010-0.326 \mathrm{mg} / \mathrm{L}$; Cd, 0.316-0.457 $\mu \mathrm{g} / \mathrm{L}$; $\mathrm{Pb}, 0.038-0.499 \mathrm{mg} / \mathrm{L}$ ) (Fig. 3) and MRE (Fig. 4) varied substantially in different soils. These variations were supposed to be associated with the variations in the chemical compositions of soils found in XRD and SEM-EDS analysis. Soil (Gillis and Miller 2000), clay (Jones and Galan 1988) and sediment (Bhakta and Munekage 2008) have significant capacity to remove heavy metals from the aquatic environment. 

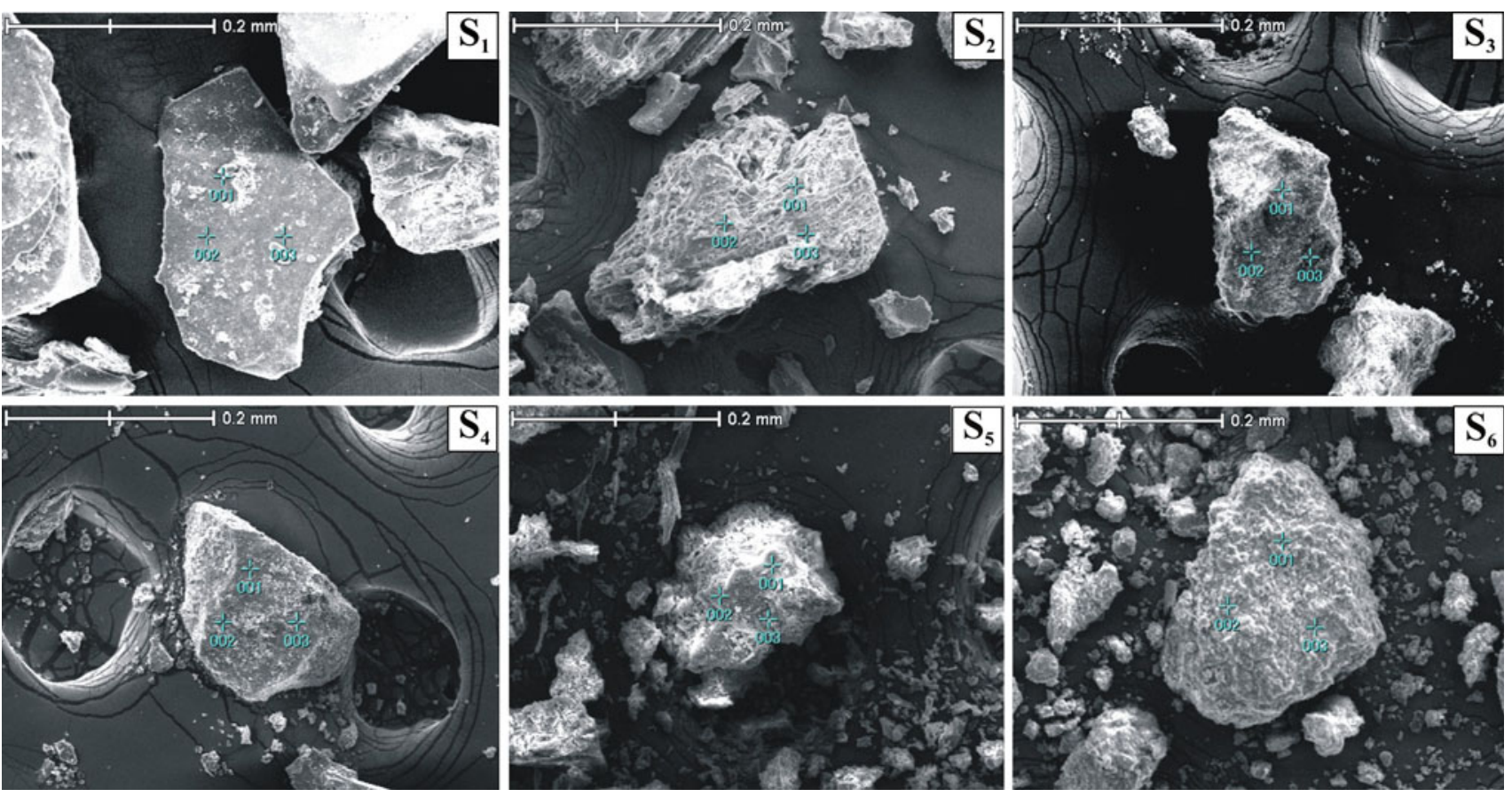

Fig. 2 SEM micrographs of six soils $\left(\mathrm{S}_{1}-\mathrm{S}_{6}\right)$ employed in the experiment

Table 3 Percentage composition of chemical constituents in six soils $\left(\mathrm{S}_{1}-\mathrm{S}_{6}\right)$ examined

\begin{tabular}{lllllll}
\hline $\begin{array}{l}\text { Chemical } \\
\text { composition } \\
(\text { wt \%) }\end{array}$ & \multicolumn{6}{l}{ Types of soil } \\
\cline { 2 - 7 } & $\mathrm{S}_{1}$ & $\mathrm{~S}_{2}$ & $\mathrm{~S}_{3}$ & $\mathrm{~S}_{4}$ & $\mathrm{~S}_{5}$ & $\mathrm{~S}_{6}$ \\
\hline $\mathrm{SiO}_{2}$ & 78.6 & 71.5 & 73 & 21.9 & 58.1 & 50.1 \\
$\mathrm{Al}_{2} \mathrm{O}_{3}$ & 12.37 & 14 & 12.9 & 4.0 & 25.8 & 38 \\
$\mathrm{FeO}$ & 0.84 & 2.38 & 7.41 & 7.75 & 6.67 & 5.07 \\
$\mathrm{~K}_{2} \mathrm{O}$ & 3.29 & 3.7 & 0.965 & 0.48 & 1.905 & 1.5 \\
$\mathrm{CaO}$ & 0.87 & 2.23 & 2.98 & 65.4 & 1.915 & 0.38 \\
$\mathrm{CuO}$ & 0 & 0 & 0 & 0 & 2.6 & 3.7 \\
$\mathrm{Na}$ & 2.11 & 1.61 & 0.565 & 0.09 & 1.125 & 0.05 \\
$\mathrm{MgO}$ & 0.285 & 2.55 & 0.76 & 1.3 & 0.69 & 0.205 \\
\hline
\end{tabular}

Arsenic removal efficiencies were higher in $\mathrm{S}_{5}$ $(242-3128 \%)$ and $\mathrm{S}_{6}(70-1500 \%)$ than those of the remaining soil types, which indicated that both $S_{5}$ and $S_{6}$ types of volcanic soil may be considered as efficient As-removing agents from water column among the examined six types of soil (Fig. 4). It also reveals that $\mathrm{S}_{5}$ is superior in removing As compared to $S_{6}$. In $S_{5}$ and $S_{6}$ soils, the major driving forces for exhibiting the maximum As-binding affinity are (1) presence of quartz, anorthite and calcium mordenite (Fig. 1) as crystalline phase and (2) presence of higher amount of $\mathrm{Al}_{2} \mathrm{O}_{3}$ as well as lower percentage of $\mathrm{SiO}_{2}$ (Table 3). Basically, these two chemical criteria of $S_{5}$ and $S_{6}$ soils are supposed to be associated with the removal of maximum amount of As from the water column compared to remaining soils. Aluminum and iron oxides were found to be good and inexpensive adsorbents in removing As from water (Gulledge and O'Connor 1973; Jeong et al. 2007). According to Zeng (2003), As (V) adsorption capacity of $\mathrm{SiO}_{2}$ is very low and no adsorption efficiency was found for As(III). Soil type $\mathrm{S}_{4}$ showed higher $\mathrm{Cd}(7-44 \%)$ and $\mathrm{Pb}(2-1,114 \%)$ removal efficiencies than the remaining five types of soil (Fig. 4), which suggests that possessing the highest amount of quartz, albite, magnesium calcite (Fig. 1) and $\mathrm{CaO}$ (65.4\%) (Table 3) in soils is an important reason for its better binding affinity to Cd and Pb. O'Hara and Surgi (1988) immobilized $\mathrm{Cd}$ and $\mathrm{Pb}$ using calcium hydroxide and phosphate. On the contrary, reduced metal removal efficiencies were found in the remaining soils $\left(S_{1}, S_{2}\right.$ and $\left.S_{3}\right)$ probably due to the presence of higher percentage of $\mathrm{SiO}_{2}$ and lower percentage of metal-specific constituents $\left(\mathrm{Al}_{2} \mathrm{O}_{3}\right.$ and $\left.\mathrm{CaO}\right)$. Our study also clearly revealed that As removal capacity of $\mathrm{Al}_{2} \mathrm{O}_{3}$ was significantly higher, whereas $\mathrm{CaO}$ showed a good $\mathrm{Cd}$ and $\mathrm{Pb}$ removal ability among the examined metal oxides (unpublished). In spite of that, we determined that $\mathrm{Al}_{2} \mathrm{O}_{3}$ and $\mathrm{CaO}$ incorporation improved the $\mathrm{As}, \mathrm{Cd}$ and $\mathrm{Pb}$ removal efficiency of soil (unpublished). It was also observed that detectable amount of organic matter content was not found in $S_{1}, S_{2}, S_{3}$ and $\mathrm{S}_{4}$, whereas $\mathrm{S}_{5}(0.09 \%)$ and $\mathrm{S}_{6}(0.86 \%)$ registered a very low level of organic matter. These results clearly supported that toxic metal sorption capacity of the investigated soils was probably regulated by the mineral/metal oxide content of the soils, but it was not influenced by organic matter content of soil. According to Jones and Galan (1988), minerals are responsible for structural adsorption, and rheological and thermal properties in clay. Furthermore, it can be 

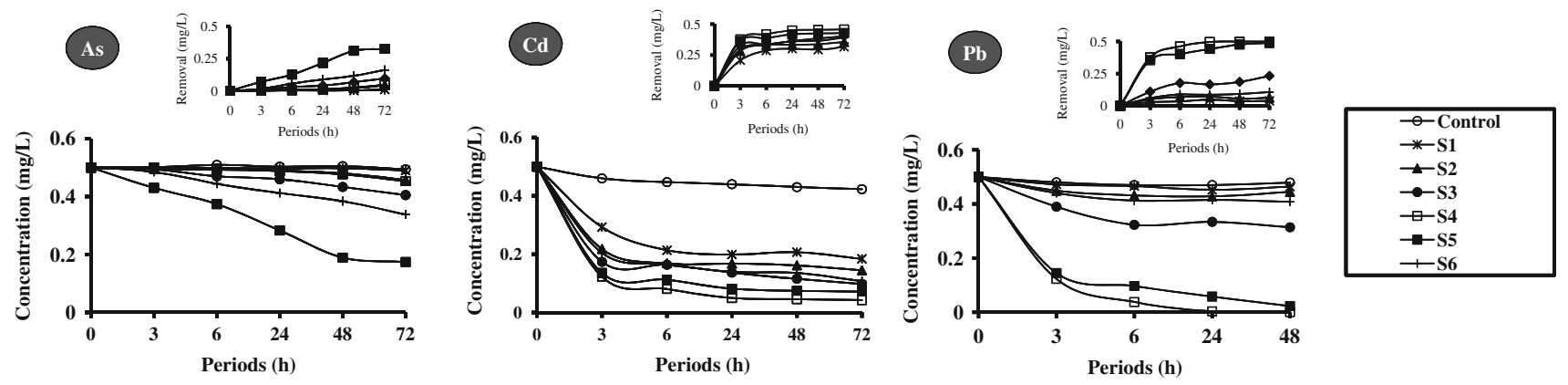

Fig. 3 Decreasing temporal responses of toxic metals concentration in water of different types of soil $\left(\mathrm{S}_{1}-\mathrm{S}_{6}\right)$ employed in experiment $($ Insets show amount of toxic metals removed from water column with time)

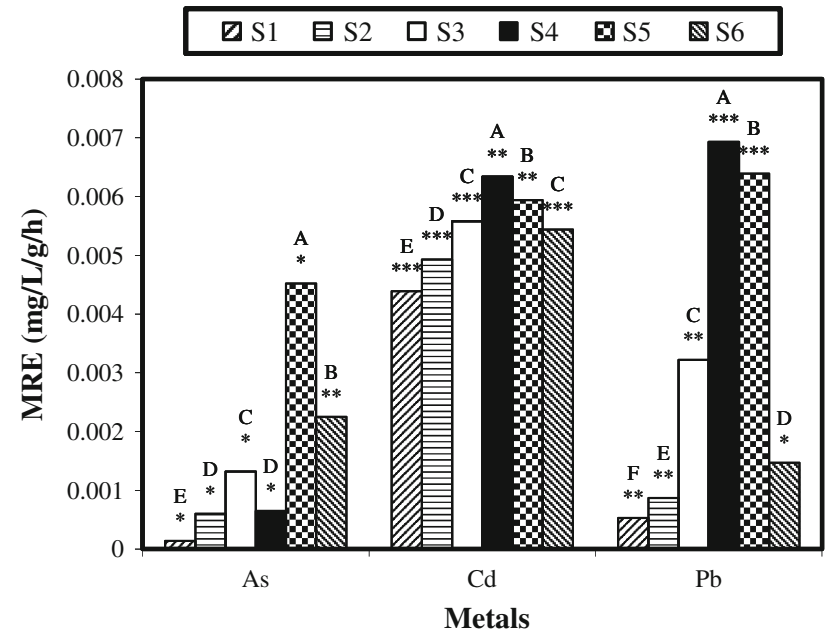

Fig. 4 Metal removal efficiency (MRE) criteria of six types of soil $\left(\mathrm{S}_{1}-\mathrm{S}_{6}\right)$. Same script $(A-F)$ over the bars of six soil types for each toxic metal revealed lack of significant difference. Asterisks $\left(^{*}\right)$ over the same three bars of each soil types in three metals depicts the preferential adsorption $(* * *>* *>*)$ of metals

demonstrated that minerals/metal oxides of soil play a significant role in metal sorption process by forming ion complex (outer and inner-sphere complex of soil) between the toxic metals of the solution and the surface functional groups of minerals in the porous soils. According to Stumm (1992), surface metal ions coordinate to water forming a Lewis acid site, and then a dissociative chemisorption (chemical bonding to the surface) leads to a hydroxylated surface with surface $\mathrm{OH}$ groups. Zeng (2003) proposed that Fe-Si binary oxide complexes improve As removal capacity. It can also be drawn herein that chemical sorption mechanism is a regulating force to remove hazardous metals from the water phase as found in zeolite (Erdem et al. 2004), because the chemical compositions of tested potential metal-removing soils are very similar to zeolite.

Critical appraisal of MRE of three metals clearly revealed that each soil type showed higher degree of removal efficiency in $\mathrm{Cd}(* * *)$, moderate degree of removal efficiency in $\mathrm{Pb}(* *)$ and lowest degree of removal efficiency in As $\left(^{*}\right)$ - i.e., $\mathrm{Cd}>\mathrm{Pb}>$ As excepting $\mathrm{S}_{4}$ and $\mathrm{S}_{5}$ types of soil which exhibited maximum removal efficiency in $\mathrm{Pb}(* * *)$ followed by $\mathrm{Cd}\left({ }^{*}\right)$ and $\mathrm{As}(*)$-i.e., $\mathrm{Pb}>\mathrm{Cd}>\mathrm{As}$ (Fig. 4). This result strongly suggested that each soil type has specific priority metal pollutant in their metal removal mechanism from aqueous phase-i.e., preferential metal removal. On the basis of preferential metal removal property, $\mathrm{Cd}, \mathrm{Pb}$ and $\mathrm{As}$ can be designated first, second and third priorities hazardous metals to remove from aqueous phase in case of $S_{1}, S_{2}, S_{3}$ and $S_{6}$ soils, respectively, whereas for $\mathrm{S}_{4}$ and $\mathrm{S}_{5}$ soils $\mathrm{Pb}, \mathrm{Cd}$ and $\mathrm{As}$ can be recognized first, second and third priorities hazardous metals to remove from aqueous phase, respectively. Erdem et al. (2004) proposed a sorption selectivity sequence of metals in zeolite. Rozada et al. (2008) suggested that pyrolyzed sludge and chemically activated sludge showed higher adsorption affinity to $\mathrm{Hg}$ than to $\mathrm{Pb}$, followed by $\mathrm{Cu}$ and $\mathrm{Cr}$.

Sorption isotherm of identified potential metal-removing soil

Since the above metal removal criteria identified the $\mathrm{S}_{5}$ soil was best for As removal and $\mathrm{S}_{4}$ soil was efficient for $\mathrm{Cd}$ and $\mathrm{Pb}$ removal, sorption isotherm studies of $\mathrm{As}, \mathrm{Cd}$ and $\mathrm{Pb}$ were performed with the corresponding soils (Fig. 5). As the doses of soils increased, equilibrium metal uptake decreased until it reached a plateau at higher soil doses in case of the three metals, $\mathrm{As}, \mathrm{Cd}$ and $\mathrm{Pb}$. In $\mathrm{S}_{5}$ soil, the correlation coefficients of Langmuir and Freundlich were 0.9397 and 0.9860 , respectively for As, whereas the correlation coefficients of $\mathrm{S}_{4}$ soil were 0.9960 (in Langmuir) and 0.8192 (in Freundlich) for $\mathrm{Cd}$ as well as -0.1013 (in Langmuir) and 0.9241 (in Freundlich) for $\mathrm{Pb}$.

In the sorption isotherm study, effect of soil dose revealed that equilibrium metal uptake decreased with the increasing soil dose. It apprehended toward the reason of having higher number of binding sites of metal oxides (especially, $\mathrm{Al}_{2} \mathrm{O}_{3}$ in akadama and kanuma and $\mathrm{CaO}$ in tuff) in the higher doses of the soil adsorbent than those of the lower soil doses for different metal ( $\mathrm{As}, \mathrm{Cd}$ and $\mathrm{Pb}$ ) ions in solution. The correlation 
coefficients revealed the experimental data of $S_{5}$ (for As) and $\mathrm{S}_{4}$ (for $\mathrm{Pb}$ ) well fitted with Freundlich rather than the Langmuir models, whereas Langmuir isotherm for $\mathrm{Cd}$ better fitted with the experimental data than the Freundlich model. In this context, it should be mentioned that though the present study is a platform for the identification of metal-removing potential soil components of the environment with an isotherm study, full screen isotherm study regarding the effect of $\mathrm{pH}$, temperature, contact time and initial concentration of different metals is required for better understanding as well as designing the optimum model of these soils based efficient adsorption reactor system before applying to the practical and commercial fields.

Ion concentration of water

Sodium (0.01-15.20 mg/L) and K (0-5.058 mg/L) ions in water increased from initial to final concentrations in As-, $\mathrm{Cd}$ - and Pb-treated soils, whereas $\mathrm{Mg}(0-1.863 \mathrm{mg} / \mathrm{L})$ and $\mathrm{Ca}(0-10.291 \mathrm{mg} / \mathrm{L})$ showed increasing trend in $\mathrm{Cd}-$ and $\mathrm{Pb}$-treated soils except As-treated soils with few variations. In control, the concentration of $\mathrm{Na}(0-0.042 \mathrm{mg} / \mathrm{L}), \mathrm{K}$ $(0-0.002 \mathrm{mg} / \mathrm{L}), \mathrm{Mg}(0-0.001 \mathrm{mg} / \mathrm{L})$ and $\mathrm{Ca}(0-0.03 \mathrm{mg} / \mathrm{L})$ showed no remarkable increment compared to the treated groups. Maximum increment of $\mathrm{Na}(15.14 \mathrm{mg} / \mathrm{L})$ was observed in $\mathrm{S}_{6}$ of As, whereas $\mathrm{K}(5.058 \mathrm{mg} / \mathrm{L}), \mathrm{Mg}$ $(1.863 \mathrm{mg} / \mathrm{L})$ and $\mathrm{Ca}(10.269 \mathrm{mg} / \mathrm{L})$ showed highest concentration increase in $\mathrm{S}_{3}, \mathrm{~S}_{5}$ and $\mathrm{S}_{4}$ of $\mathrm{Pb}$, respectively.

With some exceptions, the concentrations of the above ions were significantly increased in the water column of different soils, indicating the ion exchange mechanism between the ions of soil $(\mathrm{Na}, \mathrm{K}, \mathrm{Mg}$ and $\mathrm{Ca}$ ) and toxic metal ions ( $\mathrm{As}, \mathrm{Cd}$ and $\mathrm{Pb}$ ) of water solution on the surface of the soil particles. Furthermore, it may be suggested that due to the presence of higher amount $\mathrm{Al}_{2} \mathrm{O}_{3}$, the isomorphous replacement of $\mathrm{Si}^{4+}$ by $\mathrm{Al}^{3+}$ produces a negative charge in the lattice. The net negative charge is balanced by the exchangeable cations ( $\mathrm{Na}, \mathrm{K}$ or $\mathrm{Ca}$ ) which are exchangeable with certain cations in solutions such as As, $\mathrm{Cd}, \mathrm{Pb}, \mathrm{Zn}$ etc. (Barer 1987; Breck 1964). Therefore, it clearly demonstrated that the ion exchange mechanism also plays a role in removing toxic metals from water solution.

Practical approach of metal-contaminated water treatment: sorption, desorption and resorption

A substantial amount of As $(0.377 \mathrm{mg} / \mathrm{L})$ was removed by $\mathrm{S}_{5}$ soil, whereas $0.475 \mathrm{mg} / \mathrm{L} \mathrm{Cd}$ and $0.510 \mathrm{mg} / \mathrm{L} \mathrm{Pb}$ were removed by $\mathrm{S}_{4}$ soils separately (Table 4 ). The registered initial and final $\mathrm{pH}$ values of the treated water are also shown in the Table 4. The $\mathrm{pH}$ of treated water is close to normal water $\mathrm{pH}$ which is favorable for the environmental aspect. Arsenic desorption capacity was $\sim 95 \%$ in $\mathrm{S}_{5}$ soil, whereas $\mathrm{S}_{4}$ soil showed $\sim 93$ and $\sim 82 \%$ desorption capacities in $\mathrm{Cd}$ and $\mathrm{Pd}$, respectively. Likewise, resorption capacity of $\mathrm{S}_{5}$ soil was $\sim 88 \%$ for $\mathrm{As}$, and $\mathrm{S}_{4}$ showed $\sim 85$ and $\sim 76 \%$ resorption capacities for $\mathrm{Cd}$ and $\mathrm{Pb}$, respectively. Desorption and resorption capacities of examined soils clearly revealed that the adsorption mechanism also plays a role along with ion exchange mechanism to remove hazardous metals from water phase. Though it is difficult to determine the priority mechanism responsible for metal removal process because different mechanisms (physico-chemical sorption and ion exchange) occur simultaneously, the adsorption process can apparently be mentioned as an important mechanism. This study also indicates that it can be recycled by desorption process using EDTA. Finally, the EDTA and metal complexes can easily be separated as solid EDTA and metal salts with the help of sulfuric or hydrochloric acid to avoid the further environmental contamination.

Though practical application and environmental hazardous impacts of spent adsorbent are the major aspects for an adsorbent media, the above practical studies suggested that a small and simple chamber with continuous agitating system is a feasible and affordably convenient approach for applying the identified potential soil adsorbents in the practical field, especially in small-scale industries to treat metal-contaminated water before discharge into the environment. Apart from that application of such potential metal
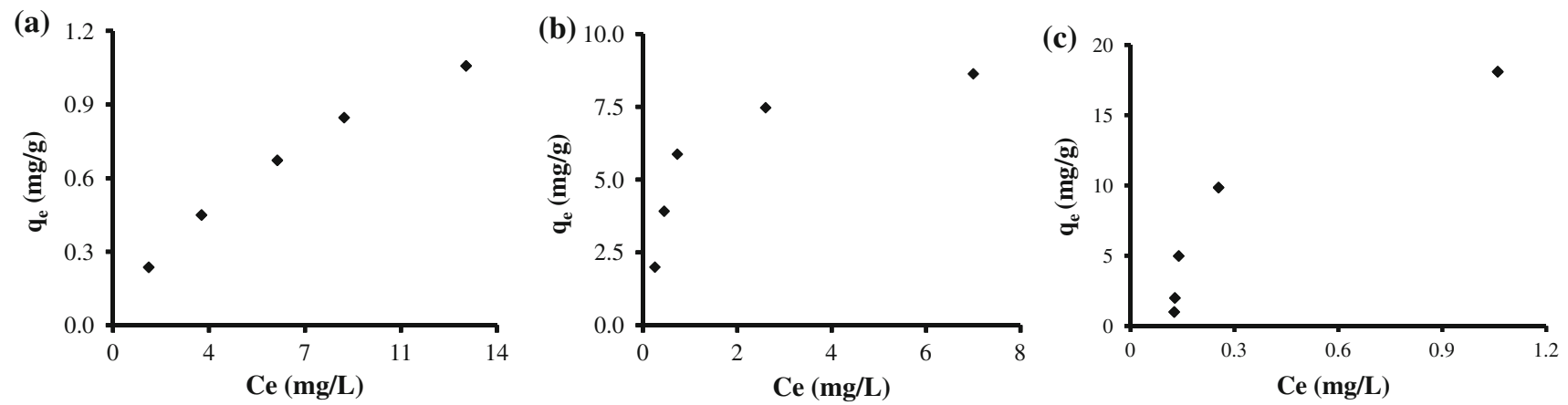

Fig. 5 Experimental sorption equilibrium curve of $\mathrm{S}_{5}$ soil for $\mathrm{As}(\mathbf{a})$ and $\mathrm{S}_{4}$ soil for $\mathrm{Cd}(\mathbf{b})$ and $\mathrm{Pb}(\mathbf{c})$ 
Table 4 Adsorption of metals by respective soils at 6th hour equilibrium state

\begin{tabular}{lllll}
\hline $\begin{array}{l}\text { Metal specific } \\
\text { soil }\end{array}$ & $\begin{array}{l}\text { Challenged } \\
\text { metal }\end{array}$ & $\begin{array}{l}\text { Removal of } \\
\text { metal }(\mathrm{mg} / \mathrm{L})\end{array}$ & $\mathrm{pH}$ & \\
\cline { 4 - 5 } & & & Initial & Final \\
\hline $\mathrm{S}_{5}$ (Akadama soil) & $\mathrm{As}$ & 0.377 & 6.75 & 6.50 \\
$\mathrm{~S}_{4}$ (Tuff soil) & $\mathrm{Cd}$ & 0.475 & 6.50 & 6.68 \\
$\mathrm{~S}_{4}$ (Tuff soil) & $\mathrm{Pb}$ & 0.510 & 6.61 & 6.89 \\
\hline
\end{tabular}

uptaking soil components as a bed in the artificial wastewater treatment, wetland system would possibly be an effective technique, though it was not considered in the present study. Removal of toxic metals from water column and fixation within this soil bed are the major functional mechanisms of such artificial wetland system of wastewater treatment. Incorporation of clay-based ceramic as a vesicle with plant in the constructed wetland treatment system is a new approach for wastewater reclamation (Bhakta and Munekage 2009; Chen et al. 2006). On the other hand, metal saturated spent soil adsorbents and beds can be recycled by the desorption process and used for land filling maintaining the permissible limit of hazardous metals.

\section{Conclusion}

The present study revealed that the investigated soils have excellent hazardous metal removal capacity (As 2.0-65.2 \%, Cd 63.2-91.4 \% and $\mathrm{Pb} 13.1-99 \%$ ) from water. Besides, an overall discussion affords drawing the following conclusions. Each type of examined soil has a specific metal sorption property which is largely governed by its specific chemical constituents by synergistic effects of physico-chemical sorption and ion exchange mechanisms. More specifically, soil ( $\mathrm{S}_{5}$, akadama) possessing higher percentage of $\mathrm{Al}_{2} \mathrm{O}_{3}$ is efficient for removing As, whereas higher $\mathrm{CaO}$ containing soil $\left(\mathrm{S}_{4}\right.$, tuff) has a promising ability to remove $\mathrm{Cd}$ and $\mathrm{Pb}$ from water. Thus, akadama soil could be used for removing the As and tuff soil would be a potential agent to treat $\mathrm{Cd}$-and $\mathrm{Pd}$-contaminated water.

No preparation cost and costly infrastructure are required to use the identified soil adsorbents. Therefore, identification by determining their chemical properties and eco-friendly application of such types of easily available potential soil components as an adsorbent tool would be a simple and low-cost eco-technology based new approach to treat the massive metal-contaminated effluents.

Acknowledgments The authors are grateful to the Government of Japan for sponsoring the JSPS research grant (No. 20380181) to carry out the present study. The authors express their sincere thanks to $\mathrm{K}$. Fuyukawa for helping in the collection of soil samples used in the experiment and to Dr. Yuhji Yamamoto for extending his kind cooperation in the XRD and SEM-EDS analysis.

\section{References}

Agrawal A, Sahu KK (2006) Kinetic and isotherm studies of cadmium adsorption on manganese nodule reside. J Haz Mat B137:915-924

Aksu Z (2005) Application of biosorption for the removal of organic pollutants: a review. Process Biochem 40:997-1026

Bailey SE, Olin TJ, Brica RM, Adrin DD (1999) A review of the potential low cost sorbents for heavy metals. Water Res 33:2469-2479

Barer RM (1987) Zeolites and clay minerals as sorbent and molecular sieves. Academic Press, New York

Barron-Zambrano J, Laborie S, Vier Ph, Rakib M, Durand G (2002) Mercury removal from aqueous solutions by complexationultrafiltration. Desalination 144:201-206

Benguella B, Benaissa H (2002) Cadmium removal from aqueous solutions by chitin: kinetics and equilibrium studies. Water Res 36:2463-2474

Bhakta JN, Munekage Y (2008) Role of ecosystem components in Cd removal process of aquatic ecosystem. Ecol Eng 32:274-280

Bhakta JN, Munekage Y (2009) Ceramic as a potential tool for water reclamation: a consize review. J Environ Prot Sci 3:147-162

Breck DW (1964) Crystalline molecular sieves. J Chem Ed 41:678

Campbell PGC (2006) Cadmium — a priority pollutant. Environ Chem $3: 387-388$

Cerino Córdova FJ, García León AM, Garcia Reyes RB, Garza González MT, Soto Regalado E, Sánchez González MN, Quezada Lopez I (2011) Response surface methodology for lead biosorption on Aspergillus terreus. Int J Environ Sci Tech 8:695-704

Chen JP, Wang X (2000) Removing copper, zinc and lead ion by granular activated carbon in pretreated fixed-bed columns. Separ Purif Tech 19:157-167

Chen TY, Kao CM, Yeh TY, Chien HY, Chao AC (2006) Application of a constructed wetland for industrial wastewater treatment: a pilot-scale study. Chemosphere 64:497-502

Choudhury H, Mudipalli A (2008) Potential considerations and concerns in the risk characterization for the interaction profiles of metals. Indian J Med Res 128:462-483

Das S, Jana BB (1999) Dose-dependent uptake and Eichhorniainduced elimination of cadmium in various organs of the freshwater mussel, Lamellidens marginalis (Linn.). Ecol Eng 12:207-229

Directive 2000/60/EC (2000) Water Framework Directive of the European Parliament and of the Council of 23 Oct 2000

Doyurum S, Celik A (2006) $\mathrm{Pb}$ (II) and Cd(II) removal from aqueous solution by olive cake. J Haz Mat B138:22-28

Erdem E, Karapinar N, Donat R (2004) The removal of heavy metal cations by natural zeolites. J Coll Interf Sci 280:309-314

Ferard JF, Jouany JM, Truhaut R, Vasseur P (1983) Accumulation of cadmium in a freshwater food chain experimental model. Ecotox Environ Saf 7:43-52

Gabaldon C, Marzal P, Alvarez-Hornos FJ (2006) Modelling Cd(II) removal from aqueous solutions by adsorption on a highly mineralized peat, batch and fixed-bed column experiments. J Chem Tech Biotech 81:1107-1112

Gillis AA, Miller DR (2000) Some local environmental effects on mercury emission and adsorption at a soil surface. Sci Total Environ 260:191-200

Gomez KA, Gomez AA (1984) Statistical Procedures for Agricultural Research. International Rice Research Institute, New York

Gulledge JH, O'Connor JT (1973) Removal of As(V) from water by adsorption on aluminium and ferric hydroxide. J Am Water Works Assoc 65:548-552

Hasan S, Krishnaiah S, Ghosh TK, Viswanath DS, Boddu VM (2006) Adsorption of divalent cadmium Cd(II) from aqueous solutions onto chitosan-coated pertite beads. Indust Eng Chem Res 45:5066-5077 
Hemond HF, Solo-Gabriele HM (2004) Children's exposure to arsenic from CCA-treated wooden decks and playground structures. Risk Anal 24:51-64

Holan ZR, Volesky B, Prasetyo I (1993) Biosorption of cadmium by biomass of marine algae. Biotech Bioeng 41:819-825

Hunsom M, Pruksathorn K, Damronglerd S, Vergnes H, Duverneuil P (2005) Electrochemical treatment of heavy metals $\left(\mathrm{Cu}^{2+}, \mathrm{Cr}^{6+}\right.$, $\mathrm{Ni}^{2+}$ ) from industrial effluent and modeling of copper reduction. Water Res 39:610-616

International Occupational Safety and Health Information Centre (1999) Metals in basics of chemical safety, Chapter 7. International Labour Organization, Geneva

Jana BB, Das S (1997) Potential of freshwater mussel (Lamellidens marginalis) for cadmium clearance in a model system. Ecol Eng 8:179-193

Jeong Y, Maohong F, Singh S, Chuang C-L, Saha B, Hans VLJ (2007) Evaluation of iron oxide and aluminum oxide as potential arsenic(V) adsorbents. Chem Eng Process 46:1030-1039

Jones BF, Galan E (1988) Sepiolite and palygorskite. In: Bailey SW (ed) Reviews in Mineralogy. Hydrous Phyllosilicates, vol 19. Mineralogical Society of America, Washington, pp 631-674

Jusoh A, Shiung LS, Ali N, Noor MJMM (2007) A simulation study of the removal efficiency of granular activated carbon on cadmium and lead. Desalination 206:9-16

Kentish SE, Stevens GW (2001) Innovations in separations technology for the recycling and re-use of liquid waste streams. Chem Eng J 84:149-159

Kratochvil D, Volesky D (1998) Advances in the biosorption of heavy metals. Tybtech 16:291-299

Murphy BL, Toole AP, Bergstrom PD (1989) Health risk assessment for arsenic contaminated soil. Environ Geochem Heal 11:163-169

Nadeem M, Nadeem R, Nadem HU, Shah SS (2005) Accumulation of lead and cadmium in different organs of chicken. Pak J Sci Res $57: 71-82$

Nouri L, Ghodbane I, Hamdaoui O, Chiha M (2007) Batch sorption dynamics and equilibrium for the removal of cadmium ions from aqueous phase using wheat bran. J Haz Mat 149:115-125
O'Hara MJ, Surgi MR (1988) Immobilization of lead and cadmium in solid residues from the combustion of refuse using lime and phosphate. Unite state patent, Patent number 4737356

Onundi YB, Mamun AA, Al Khatib MF, AlSaadi MA, Suleyman AM (2011) Heavy metals removal from synthetic wastewater by a novel nano-size composite adsorbent. Int $\mathrm{J}$ Environ Sci Tech 8:799-806

Pacheco S, Tapia J, Medina M, Rodriguez R (2006) Cadmium ions adsorption in simulated wastewater using structured aluminasilica nanoparticles. J Non-Cryst Solid 352:5475-5481

Peterlene WS, Winkler-Hechenleitner AA, Pineda EAG (1999) Adsorption of $\mathrm{Cd}(\mathrm{II})$ and $\mathrm{Pb}(\mathrm{II})$ onto functionalized formic lignin from sugarcane bagasse. Biores Tech 68:95-100

Roberts JR (1999) Metal toxicity in children. In: training manual on pediatric environmental health: putting it into practice. Emeryville, CA, Children's Environmental Health Network. http:// www.cehn.org/cehn/trainingmanual/(pdf/manual-full.pdf)

Robertson FN (1989) Arsenic in ground-water under oxidizing conditions, south-west United States. Environ Geochem Heal 11:171-185

Rozada F, Otero M, Moran A, Garcia AI (2008) Adsorption of heavy metals onto sewage sludge-derived materials. Biores Technol 99:6332-6338

Stumm W (1992) Chemistry of the Solid - Water Interface. Wiley, New York

Tashauoei HR, Movahedian Attar H, Amin MM, Kamali M, Nikaeen M, Vahid Dastjerdi M (2010) Removal of cadmium and humic acid from aqueous solutions using surface modified nanozeolite A. Int J Environ Sc Tech 7:497-508

Zavvar Mousavi H, Seyedi SR (2011) Nettle ash as a low cost adsorbent for the removal of Nickel and Cadmium from wastewater. Int J Environ Sci Tech 8:195-202

Zeng L (2003) A method for preparing silica-containing iron(III) oxide adsorbents for arsenic removal. Water Res 37:4351-4358 